\title{
Maternal serum placental growth hormone, insulin-like growth factors and their binding proteins at 20 weeks' gestation in pregnancies complicated by gestational diabetes mellitus
}

\author{
Shutan Liao, ${ }^{1,2,5}$ Mark H. Vickers, ${ }^{1,2}$ Rennae S. Taylor, ${ }^{3}$ Mhoyra Fraser, ${ }^{4}$ \\ Lesley M.E. McCowan, ${ }^{3}$ Philip N. Baker, ${ }^{1,2,6}$ Jo K. Perry ${ }^{1,2}$ \\ ${ }^{1}$ Liggins Institute, University of Auckland, Auckland, New Zealand; ${ }^{2}$ Gravida: National Centre for Growth and Development, \\ New Zealand; ${ }^{3}$ Department of Obstetrics and Gynaecology, University of Auckland, Auckland, New Zealand; ${ }^{4}$ Department \\ of Physiology, University of Auckland, Auckland, New Zealand; ${ }^{5}$ The First Affiliated Hospital of Sun Yat-sen University, \\ Guangzhou, China; ${ }^{6}$ College of Medicine, Biological Sciences and Psychology, University of Leicester, UK
}

\begin{abstract}
OBJECTIVE: To investigate whether maternal serum concentrations of placental growth hormone (GH-V), insulin-like growth factor (IGF) 1 and 2, and IGF binding proteins (IGFBP) 1 and 3 were altered in pregnancies complicated by gestational diabetes mellitus (GDM). METHOD: In a nested case-control study, GDM cases $(n=28)$ and matched controls $(n=28)$ were selected from the Screening for Pregnancy Endpoints (SCOPE) biobank in Auckland, New Zealand. Maternal serum hormone concentrations at 20 weeks of gestation were determined by enzyme-linked immunosorbent assay (ELISA). RESULTS: There was no significant difference in maternal serum GH-V concentration in the GDM group compared to the control group $(1.64 \pm 0.11 \mathrm{ng} / \mathrm{ml}$ vs. $1.38 \pm 0.10 \mathrm{ng} / \mathrm{ml}, \mathbf{p}=0.079)$. However, GDM cases who delivered large for gestational age (LGA) babies had significantly higher serum GH-V concentrations compared to non-diabetic control cases. Maternal IGF-1 concentrations in GDM pregnancies were significantly higher than in controls $(275.7 \pm 11.5 \mathrm{ng} / \mathrm{ml} \mathrm{vs.} 218.5 \pm 11.1 \mathrm{ng} / \mathrm{ml}, \mathrm{p}<0.001)$. Maternal IGFBP-1 concentrations were significantly lower in GDM pregnancies than in controls $(41.04 \pm 3.42 \mathrm{ng} / \mathrm{ml}$ vs. $67.58 \pm 6.17 \mathrm{ng} / \mathrm{ml}, \mathrm{p}<0.001)$. There were no significant differences in serum IGF-2 and IGFBP-3 concentrations between groups. CONCLUSION: Concentrations of IGF-1 and IGFBP-1 in maternal serum were altered in GDM pregnancies compared to controls, suggesting that the IGF axis plays a role in the development of this condition. GH-V may be associated with macrosomia as increased maternal GH-V was observed in GDM cases who delivered LGA babies.
\end{abstract}

Key words: Binding proteins, Gestational diabetes mellitus, Insulin-like growth factor, Placental growth hormone, Pregnancy 


\section{INTRODUCTION}

Gestational diabetes mellitus (GDM), defined as glucose intolerance with onset or first recognition during pregnancy, represents a failure to maintain normal glucose tolerance during the metabolic stress of pregnancy. ${ }^{1}$ It affects $5.8-12.9 \%$ of all pregnancies worldwide ${ }^{2}$ and is associated with multiple gestational complications, including macrosomia, dystocia, stillbirth, neonatal hypoglycaemia and respiratory distress. ${ }^{3}$ Both the foetus and the mother have increased risk for metabolic disorders and diabetes in later life. ${ }^{4}$

Placental growth hormone variant $(\mathrm{GH}-\mathrm{V})$ is the product of the $G H-V$ gene specifically expressed in the syncytiotrophoblast layer of the human placenta. ${ }^{5}$ $\mathrm{GH}-\mathrm{V}$ differs from pituitary growth hormone $(\mathrm{GH}-\mathrm{N})$ by 13 amino acids and shares similar physiological effects with GH-N ${ }^{6,7}$ GH-N is mainly secreted in a pulsatile fashion from the pituitary, while GH-V is secreted from the placenta in a non-pulsatile manner during human pregnancy. ${ }^{8} \mathrm{GH}-\mathrm{V}$ is thought to play a key role in maternal adaptation to pregnancy as it stimulates foetal growth, gluconeogenesis, lipolysis, and anabolism thereby increasing substrate supply for the foetoplacental unit. ${ }^{69} \mathrm{We}$ and others have demonstrated that transgenic expression or administration of exogenous $\mathrm{GH}-\mathrm{V}$ causes insulin resistance in mice. ${ }^{10-12}$ A positive association between maternal $\mathrm{GH}-\mathrm{V}$ and foetal growth has been found in previous studies. ${ }^{13-15}$ Increased maternal GH-V concentrations were also observed in large for gestational age (LGA) pregnancies. ${ }^{16}$ Further, it is thought that GH-V increases maternal concentrations of other important growth factors, such as insulin-like growth factor (IGF)-1, during pregnancy. ${ }^{17-19} \mathrm{IGFs}$ and their binding proteins (IGFBP) affect maternal metabolism and act as endocrine signals to enhance placental function and foetal growth. ${ }^{20,21}$ The structural homology between IGFs and insulin and the hypoglycaemic activity regulated by IGFBPs suggest that IGFs and their binding proteins have an intrinsic role in glucose metabolism and homeostasis. ${ }^{22}$ Limited studies implicate GH-V as a potential biomarker of GDM. ${ }^{14,23}$ Dysregulations of IGFs and their binding proteins were also observed in diabetic pregnancies. ${ }^{24-26}$

The aim of this study was to determine whether maternal serum concentrations of GH-V, IGF-1 and
2, IGFBP-1 and 3 at 20 weeks of gestation were altered in pregnancies complicated by GDM. We also hypothesized that these hormone were correlated with birth weight and maternal glycaemic status.

\section{MATERIALS AND METHODS}

Ethical approval was obtained from New Zealand Health and Disability Ethics Committees (AKX/02/00/364/AM03) and all women provided written informed consent. Between November 2004 and October 2007, 2,032 nulliparous women with singleton pregnancies were recruited to the Screening for Pregnancy Endpoints (SCOPE) study in Auckland, New Zealand. The inclusion criteria has been described previously. ${ }^{27}$

Participants were interviewed and examined by a SCOPE research midwife at 15 and 20 weeks of gestation. At the first visit, detailed clinical and demographic data were collected and entered into an internet accessed, central database with a complete audit trail (MedSciNet, Stockholm, Sweden). Maternal serum samples were collected at 20 weeks and stored at $-80^{\circ} \mathrm{C}$ for subsequent analyses. The specimens did not undergo any freeze/thaw cycles prior to these analyses. Birth weight was recorded using electronic scales at the time of birth. Customized birth weight centile adjusted for mother's height and weight at 15 weeks' visit, ethnicity, sex and gestation at delivery, was calculated to allow comparison of relative foetal growth across a range of gestational ages. Small for gestational age (SGA) and LGA were defined as birth weight $<10^{\text {th }}$ and $>90^{\text {th }}$ customized birth weight centiles, respectively. All participants underwent the glucose screening ( $50 \mathrm{~g}$ polycose) from 15 to 28 weeks depending on risk factors. Participants who had abnormal glucose screening results or who were at high risk of developing GDM were advised to perform a two-hour $75 \mathrm{~g}$ oral glucose tolerance test (OGTT). GDM for the purposes of this case control study was diagnosed by International Association of Diabetes and Pregnancy Study Groups (IADPSG) criteria based on Hyperglycemia and Adverse Pregnancy Outcome (HAPO) data (fasting plasma glucose $\geq 5.1$ $\mathrm{mmol} / \mathrm{L}$ or $1 \mathrm{~h}$ glucose $\geq 10.0 \mathrm{mmol} / \mathrm{L}$ or $2 \mathrm{~h}$ glucose $\geq 8.5 \mathrm{mmol} / \mathrm{L}){ }^{28}$

In this nested case-control study, 28 GDM cases 
were selected from the New Zealand SCOPE cohort and matched by ethnicity, age ( \pm 3 years), and body mass index (BMI) $\left( \pm 3 \mathrm{~kg} / \mathrm{m}^{2}\right)$ to 28 controls.

\section{Materials}

Recombinant human GH-V (22 kDa) was purchased from Protein Laboratories Rehovot (Rehovot, Israel) and was reconstituted in $0.4 \% \mathrm{NaHCO}_{3} \mathrm{pH}$ 9. ${ }^{29}$ Human GH-V monoclonal antibodies 78.8E8 (E8; MCA5827G) and 78.7C12 (7C12; MCA5828G) were obtained from Bio-Rad AbD Serotec (NC, US). E8 does not cross-react with GH-N or prolactin; $7 \mathrm{C} 12$ shows some cross-reactivity with GH-N (5\%) as per the manufacturer's documentation. Antibody $7 \mathrm{C} 12$ was biotinylated using a LYNX Rapid Biotin Antibody Conjugation Kit (Bio-Rad AbD Serotec) according to the manufacturer's instructions.

\section{GH-V ELISA procedure}

We have previously described the development and validation of an in-house enzyme-linked immunosorbent assay (ELISA) for the measurement of $\mathrm{GH}-\mathrm{V}$ in serum. ${ }^{30}$ In brief, microtiter plates were coated with antibody E8 diluted in phosphate buffer $(0.1 \mathrm{M}$ Sodium Carbonate, $\mathrm{pH}$ 9.5) at a concentration of 2 $\mu \mathrm{g} / \mathrm{ml}$ by overnight incubation at $4^{\circ} \mathrm{C}$. Coated plates were washed three times with wash buffer (PBS-T; 10 $\mathrm{mM}$ phosphate buffer $\mathrm{pH} 7.4,150 \mathrm{mM} \mathrm{NaCl}, 0.05 \%$ Tween 20). Blocking was achieved by 1 hour incubation at room temperature with Ultrablock (Bio-Rad $\mathrm{AbD}$ Serotec). Standards were prepared from $\mathrm{GH}-\mathrm{V}$ solution with a range from 0.078 to $5 \mathrm{ng} / \mathrm{ml}$. Standards and 1:2 diluted serum samples were incubated for 2 hours at room temperature, then washed three times. All serum samples were measured in duplicate. $8 \mu \mathrm{g} /$ $\mathrm{ml}$ biotinylated antibody $\mathrm{C} 12$ was added and incubated for 1 hour. After being washed three times, $200 \mathrm{ng} / \mathrm{ml}$ horseradish peroxidase conjugated streptavidin (BioRad AbD Serotec) was added and incubated for 30 minutes. The microtiter plates were washed four times. End-point detection was processed by using 3, 3', 5, 5'-Tetramethylbenzidine (TMB) Substrate Reagent Set (BD Biosciences) and stop solution $\left(2 \mathrm{~N} \mathrm{H}_{2} \mathrm{SO}_{4}\right)$. Absorbance was read at $450 \mathrm{~nm}$ and $590 \mathrm{~nm}$ within 30 minutes of stopping reaction. Serum samples were spiked with GH-V and the average recovery rate was $106 \%$. Coefficients of variation (CV) of intra-assay and inter-assay were $4.8 \%$ and $6.8 \%$, respectively.

\section{Serum analysis}

Serum total IGF-1, total IGF-2, IGFBP-1, and IGFBP-3 were assayed with human-specific ELISA as per the manufacturer's instructions (Mediagnost, Germany).

\section{Statistical analysis}

Concentrations of GH-V, IGF-2, and IGFBP-1 were positively skewed. Data were log-transformed to improve the approximation of normal distribution and linearize relationships where appropriate. Data are expressed as means \pm S.E.M unless stated otherwise. Group means were compared using a Student's $t$ test. Categorical variables were compared using chi-square or Fisher's exact test. Pearson's coefficient was used to determine correlations between variables, presented as $r$ values. Multivariate linear regression analysis was adopted to determine the association of maternal hormone concentrations with changes in glucose levels. All analyses were conducted using IBM SPSS Statistics 21 . A p-value of $<0.05$ was accepted as statistically significant.

\section{RESULTS}

The demographic and clinical details are shown in Table 1.

\section{Concentrations of maternal GH-related hormones}

There was no significant difference in maternal serum GH-V concentration in the GDM group at 20 weeks of gestation when compared with the control group $(1.64 \pm 0.11 \mathrm{ng} / \mathrm{ml}$ vs. $1.38 \pm 0.10 \mathrm{ng} / \mathrm{ml}$, $\mathrm{p}=0.079$ ) (Figure 1A). However, GDM cases who delivered LGA babies $(n=7)$ had significantly higher serum GH-V concentrations compared to non-diabetic controls $(\mathrm{n}=28)(1.93 \pm 0.21 \mathrm{ng} / \mathrm{ml}$ vs. $1.38 \pm 0.10$ $\mathrm{ng} / \mathrm{ml}, \mathrm{p}=0.02)$. Maternal serum IGF-1 concentrations in GDM pregnancies were significantly higher than in the control group $(275.7 \pm 11.5 \mathrm{ng} / \mathrm{ml}$ vs. $218.5 \pm$ $11.1 \mathrm{ng} / \mathrm{ml}, \mathrm{p}<0.001$ ) (Figure 1B). Maternal serum IGFBP-1 concentrations were significantly lower in GDM pregnancies than in controls $(41.04 \pm 3.42 \mathrm{ng} /$ $\mathrm{ml}$ vs. $67.58 \pm 6.17 \mathrm{ng} / \mathrm{ml}, \mathrm{p}<0.001$ ) (Figure 1D). There was no significant difference in serum IGF-2 or IGFBP-3 concentrations between groups (Figure $1 \mathrm{C}$ and $\mathrm{E})$. 
Table 1. Demographic and clinical findings

\begin{tabular}{lccc}
\hline & $\begin{array}{c}\text { GDM } \\
\mathbf{n = 2 8}\end{array}$ & $\begin{array}{c}\text { Control } \\
\mathbf{n = 2 8}\end{array}$ & P value \\
\hline Maternal characteristics & & & \\
Maternal age (yrs) & $31.4(0.9)$ & $31.3(0.8)$ & - \\
Socioeconomic index* & $47(3)$ & $48(3)$ & $\mathrm{ns}$ \\
Caucasian, n (\%) & $18(64.3)$ & $18(64.3)$ & - \\
Family history of diabetes & $10(35.7)$ & $6(21.4)$ & $\mathrm{ns}$ \\
Smoked at 15 wks, n (\%) & $3(10.7)$ & $5(17.9)$ & $\mathrm{ns}$ \\
Any alcohol intake at 15 & $2(7.1)$ & $2(7.1)$ & $\mathrm{ns}$ \\
wks, n (\%) & & & \\
BMI at 15 wks (kg/m $\left.{ }^{2}\right)$ & $27.2(0.9)$ & $26.2(0.8)$ & - \\
Gestational age at delivery & $38.2(0.4)$ & $39.6(0.2)$ & 0.0054 \\
(wks) & & & \\
Infant characteristics & & & \\
Birth weight (g) & $3449(101)$ & $3460(85)$ & $\mathrm{ns}$ \\
SGA at birth & $2(7.1)$ & $0(0)$ & $\mathrm{ns}$ \\
LGA at birth & $7(25)$ & $4(14.3)$ & $\mathrm{ns}$ \\
Male, n (\%) & $16(57.1)$ & $15(53.6)$ & $\mathrm{ns}$ \\
\hline Results expressed as mean (SEM) & & \\
\hline
\end{tabular}

Results expressed as mean (SEM) or $\mathrm{n}(\%)$; ns, not significant. *Socioeconomic index calculated using the New Zealand Socioeconomic Index guide (1996).

\section{Correlation analysis}

In the GDM group, maternal IGF-1 concentration was positively related to the changes in $\mathrm{GH}-\mathrm{V}$ and IGFBP-3 but negatively related to the IGFBP-1 concentrations (Table 2). Maternal fasting glucose concentration in OGTT was positively related to IGF-1 $(r=0.38, p=0.046)$ and negatively related to IGFBP-1 $(r=-0.465, p=0.013)$, but these correlations were not seen with 1 hour and 2 hour OGTT measurements. In a multivariate analysis, which included maternal age, ethnicity, socioeconomic status, family history of diabetes, smoking and drinking habits, and maternal BMI as explanatory variables, this model eliminated the significant associations of IGF-1 and IGFBP-1 with fasting glucose, as fasting glucose was strongly associated with BMI ( $<<0.001)$ (Table 3 ). There was no correlation between maternal GH-V, IGF-1, IGFBP-1 or IGFBP-3, and customized birth weight centiles in the GDM group.

In the control group, maternal IGF-1 concentration was positively associated with GH-V and IGFBP-3
Table 2. Pearson's correlation coefficients between GH-related hormones

\begin{tabular}{lcc}
\hline Parameter & $\mathbf{r}$ & P value \\
\hline GDM group & & \\
IGF-1 vs. GH-V & 0.417 & 0.03 \\
IGF-2 & -0.155 & 0.432 \\
IGFBP-1 & -0.564 & 0.002 \\
IGFBP-3 & 0.418 & 0.027 \\
Control group & & \\
IGF-1 vs. GH-V & 0.511 & 0.006 \\
IGF-2 & -0.238 & 0.222 \\
IGFBP-1 & -0.348 & 0.069 \\
IGFBP-3 & 0.499 & 0.007 \\
\hline
\end{tabular}

(Table 2). In addition, maternal IGF-1 had a negative relationship with customized birth weight centiles $(\mathrm{r}=-0.395, \mathrm{p}=0.038)$.

\section{DISCUSSION}

In this nested case-control study of GDM pregnancies, we found that maternal serum concentration of GH-V at 20 weeks of gestation was not altered in pregnancies complicated by GDM, although maternal $\mathrm{GH}-\mathrm{V}$ was increased in GDM cases who delivered LGA babies. In addition, we found that maternal IGF-1 concentrations were significantly higher in GDM pregnancies compared to controls and that IGFBP-1 concentrations were significantly lower in GDM pregnancies compared to controls.

Human pregnancy is characterized by a series of metabolic changes that induce a physiologic form of insulin resistance. GDM develops when insulin secretion is inadequate to compensate for this insulin resistance. The rationale for this study was that $\mathrm{GH}-\mathrm{V}$ is thought to be the primary regulator of IGF-I in normal and abnormal human pregnancies and to be a potential candidate to mediate the insulin resistance of pregnancy. ${ }^{10,17}$ Previously we treated both pregnant and non-pregnant female mice with recombinant $\mathrm{GH}-\mathrm{V}$ and found that $\mathrm{GH}-\mathrm{V}$ reduced maternal insulin sensitivity in a dose-dependent manner. ${ }^{11,12}$ We therefore hypothesized that the maternal serum GH-V would also be altered in GDM pregnancies. However, a direct diabetogenic effect 
A

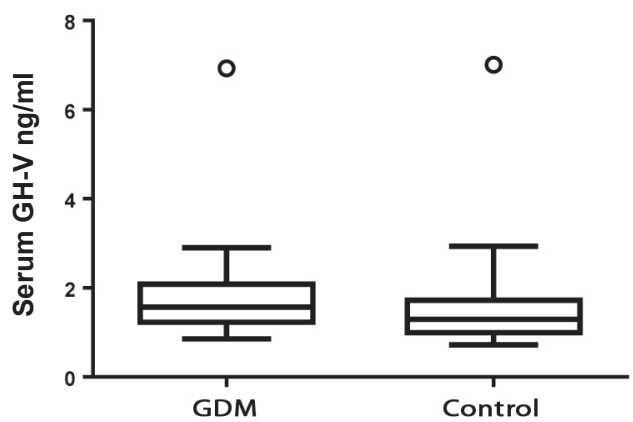

C

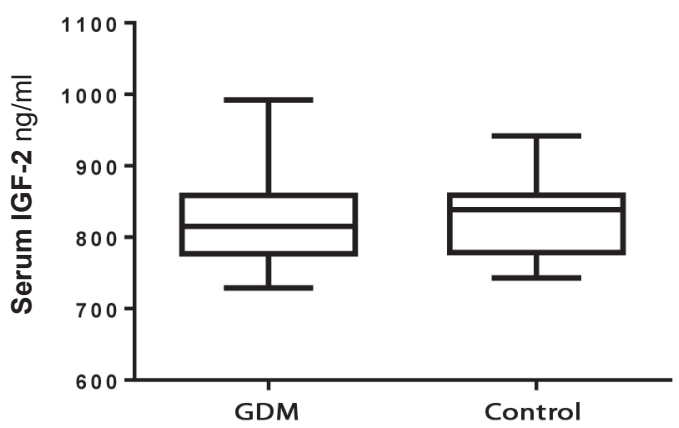

$E$

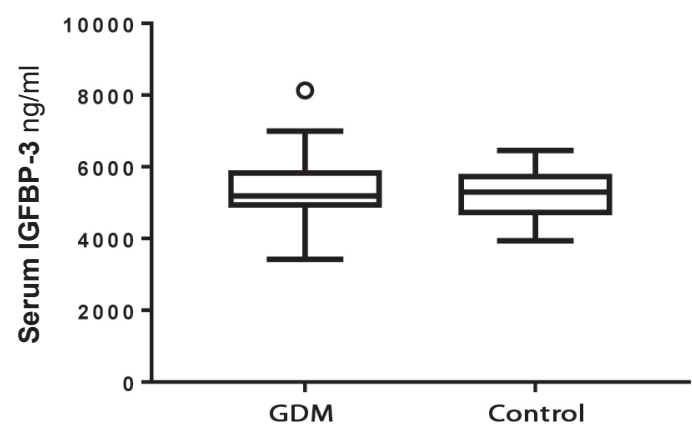

B

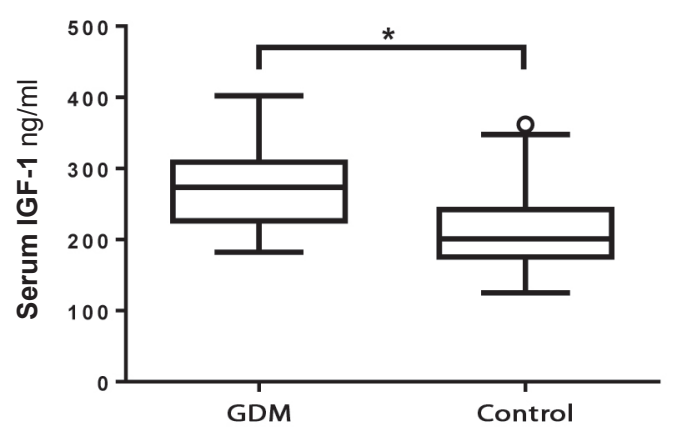

D

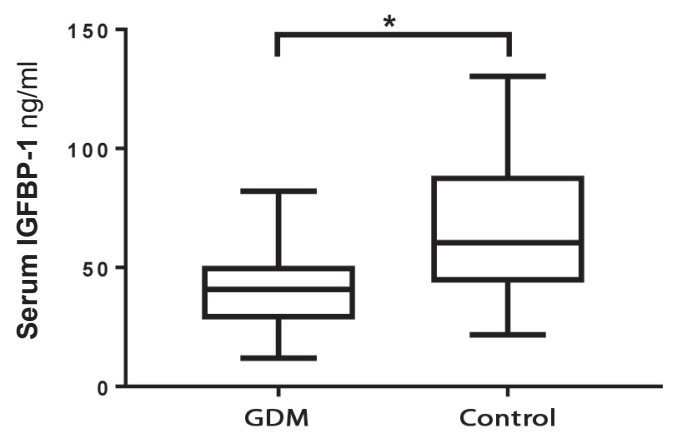

Figure 1. Serum GH-V, IGF-1, IGF-2, IGFBP-1 and IGFBP-3 concentrations. Data are shown as Tukey box-whisker plots (median, 25 th centile, 75 th centile and range). Outliers are presented as hollow symbols. ${ }^{*} \mathrm{p}<0.05$.

of GH-V at 20 weeks of gestation was not supported by the present findings.

Limited studies suggest a possible regulatory effect of glucose levels on GH-V secretion. Patel et al observed a dose-dependent inhibition of GH-V secretion by glucose in human placental explants and in trophoblast cultures. ${ }^{31}$ Bjorklund et al described an increase in $\mathrm{GH}-\mathrm{V}$ during a hyperinsulinaemic hypoglycaemic clamp in pregnant Type 1 diabetes patients. ${ }^{32}$ No studies to date have demonstrated higher levels of GH-V in diabetic pregnancies. McIntyre et al found that maternal GH-V concentrations were positively correlated with maternal glycaemia in women with established Type 1 and Type 2 diabetes, particularly in the postprandial state. ${ }^{14}$ However, the study by McIntyre et al and two other studies conducted by Higgins et al, and Verhaeghe et al failed 
Table 3. Multiple linear regression results after adjusting for potential confounders (maternal age, ethnicity, socioeconomic status, family history of diabetes, smoking and drinking habits, and maternal BMI). Model 1: association between fasting glucose level and IGF-1; Model 2: association between fasting glucose level and IGFBP-1. Fasting glucose was the dependent variable. Socioeconomic status was represented by socioeconomic index. Categorical variables were coded by dummy variables (ethnicity: Caucasian $=1 /$ non-Caucasian $=0$; family history of diabetes: yes $=1 /$ no $=0$; smoking and drinking habits: yes $=1 /$ no $=0$ )

\begin{tabular}{|c|c|c|c|c|}
\hline Variables & Coefficient Beta & Std. Error & $\mathrm{t}$ & P value \\
\hline \multicolumn{5}{|l|}{ Model $1\left(\mathrm{R}^{2}=0.718\right)$} \\
\hline Maternal age & -0.017 & 0.026 & -0.654 & 0.521 \\
\hline Ethnicity & -0.659 & 0.354 & -1.860 & 0.078 \\
\hline Socioeconomic status & 0.010 & 0.008 & 1.338 & 0.197 \\
\hline Family history of diabetes & 0.152 & 0.355 & 0.428 & 0.673 \\
\hline Smoking & 1.029 & 0.408 & 2.524 & 0.021 \\
\hline Drinking & 0.481 & 0.570 & 0.844 & 0.409 \\
\hline Maternal BMI & 0.101 & 0.024 & 4.203 & $<0.001$ \\
\hline IGF-1 & 0.003 & 0.002 & 1.452 & 0.163 \\
\hline \multicolumn{5}{|l|}{ Model $2\left(\mathrm{R}^{2}=0.688\right)$} \\
\hline Maternal age & -0.012 & 0.027 & -0.452 & 0.657 \\
\hline Ethnicity & -0.773 & 0.364 & -2.122 & 0.047 \\
\hline Socioeconomic status & 0.009 & 0.008 & 1.120 & 0.277 \\
\hline Family history of diabetes & -0.047 & 0.354 & -0.132 & 0.897 \\
\hline Smoking & 1.052 & 0.439 & 2.398 & 0.027 \\
\hline Drinking & 0.337 & 0.594 & 0.567 & 0.578 \\
\hline Maternal BMI & 0.107 & 0.032 & 3.384 & 0.003 \\
\hline IGFBP-1 & -0.003 & 0.011 & -0.266 & 0.793 \\
\hline
\end{tabular}

to show differences between $\mathrm{GH}-\mathrm{V}$ concentrations in women with normal glucose tolerance and diabetic patients. ${ }^{33,34}$ Further, Fuglsang et al demonstrated that the increase in insulin requirements during pregnancy in Type 1 diabetes was not related to GH-V levels. ${ }^{23,35}$ In our study, GH-V concentration at 20 weeks' gestation was not altered in GDM pregnancies. Although blood glucose levels are regulated primarily by adjustments in insulin concentrations, accumulating evidence indicates a complementary role of IGF-1 through its insulin-like activity. ${ }^{36} \mathrm{~A}$ family of six IGFBPs has been characterized to prolong IGF halflife in the circulation and regulate IGF-1 bioactivity. ${ }^{37}$ Their relationships are complex. IGFBPs not only regulate IGFs bioavailability but also have biological activity that is independent of IGF. ${ }^{38}$ Moreover, the hypothesis has been made that cleavage of the IGFBPs into fragments with lower affinity to IGFs allows for increased IGF receptor activation. ${ }^{39}$ As much as $99 \%$ of IGF-1 in the circulation is bound to IGFBP-3 with an acid-labile subunit to form a $150 \mathrm{kDa}$ ternary complex. However, the exact role of IGFBP-3 in glucose metabolism, either a protective effect or enhancing effect on insulin resistance, is still unclear. ${ }^{40-43}$ Although it is less abundant than IGFBP-3, IGFBP-1 has been proposed as playing an important role in glucose homeostasis as a dynamic regulator of IGF bioactivity. ${ }^{44-47}$ It has been shown that conditions characterized by insulin resistance are associated with decreased IGFBP-1 levels. ${ }^{48,49}$ In GDM patients, increased IGF-1 and decreased IGFBP-1 concentrations were observed in maternal serum at mid-late pregnancy (24 weeks onwards)..$^{50-52}$ Qiu et al also reported that free IGF-1 and IGFBP-1 at 13 weeks had an inverse association with the subsequent GDM risk..$^{53}$ Our study provides further evidence for the change of the IGFs and IGFBPs at 20 weeks of gestation in GDM pregnancies.

The findings of our study indicate that the maternal serum concentration of placental growth hormone 
at 20 weeks' gestation is unlikely to be useful in the early prediction of GDM. However, only a single sampling time-point ( 20 weeks) was applied in this study and the sample sizes were relatively small. Maternal levels of GH-V increase dramatically during mid-late pregnancy. ${ }^{54}$ Large-scale prospective studies to investigate the change of $\mathrm{GH}-\mathrm{V}$ during pregnancy complicated by GDM would provide valuable insights and support our findings.

\section{ACKNOWLEDGMENTS}

The New Zealand SCOPE study was funded by the New Enterprise Research Fund, Foundation for Research Science and Technology; Health Research Council (04/198); Evelyn Bond Fund, Auckland District Health Board Charitable Trust. This work was funded by The Maurice and Phyllis Paykel Trust and Gravida: National Centre for Growth and Development.

\section{CONFLICT OF INTEREST}

The authors declare that they have no conflict of interest.

\section{REFERENCES}

1. Colagiuri S, Falavigna M, Agarwal MM, et al, 2014 Strategies for implementing the WHO diagnostic criteria and classification of hyperglycaemia first detected in pregnancy. Diabetes Res Clin Pract 103: 364-372.

2. Zhu Y, Zhang C, 2016 Prevalence of Gestational Diabetes and Risk of Progression to Type 2 Diabetes: a Global Perspective. Curr Diab Rep 16: 7.

3. Langer O, Yogev Y, Most OXenakis EM, 2005 Gestational diabetes: the consequences of not treating. Am J Obstet Gynecol 192: 989-997.

4. Catalano PM, Kirwan JP, Haugel-de Mouzon SKing J, 2003 Gestational diabetes and insulin resistance: role in short- and long-term implications for mother and fetus. J Nutr 133: 5 Suppl 2: 1674-1683.

5. Hirt H, Kimelman J, Birnbaum MJ, et al, 1987 The human growth hormone gene locus: structure, evolution, and allelic variations. DNA 6: 59-70.

6. Alsat E, Guibourdenche J, Luton D, Frankenne FEvainBrion D. 1997 Human placental growth hormone. Am J Obstet Gynecol 177: 1526-1534.

7. Alsat E, Guibourdenche J, Couturier AE, vain-Brion D. 1998 Physiological role of human placental growth hormone. Mol Cell Endocrinol 140: 121-127.

8. Eriksson L, Frankenne F, Eden S, Hennen G, Von
Schoultz B, 1989 Growth hormone 24-h serum profiles during pregnancy--lack of pulsatility for the secretion of the placental variant. Br J Obstet Gynaecol 96: 949953.

9. Newbern D,Freemark M, 2011 Placental hormones and the control of maternal metabolism and fetal growth. Curr Opin Endocrinol Diabetes Obes 18: 409-416.

10. Barbour LA, Shao J, Qiao L, et al, 2002 Human placental growth hormone causes severe insulin resistance in transgenic mice. Am J Obstet Gynecol 186: 512-517.

11. Liao S, Vickers MH, Stanley JL, et al, 2016 The Placental Variant of Human Growth Hormone Reduces Maternal Insulin Sensitivity in a Dose-Dependent Manner in C57BL/6J Mice. Endocrinology 157: 1175-1186.

12. Liao S, Vickers MH, Evans A, et al, 2016 Comparison of pulsatile vs. continuous administration of human placental growth hormone in female C57BL/6J mice. Endocrine: 1-13.

13. Chellakooty M, Vangsgaard K, Larsen T, et al, 2004 A longitudinal study of intrauterine growth and the placental growth hormone $(\mathrm{GH})$-insulin-like growth factor I axis in maternal circulation: association between placental GH and fetal growth. J Clin Endocrinol Metab 89: 384-391.

14. McIntyre HD, Serek R, Crane DI, et al, 2000 Placental growth hormone (GH), GH-binding protein, and insulinlike growth factor axis in normal, growth-retarded, and diabetic pregnancies: correlations with fetal growth. J Clin Endocrinol Metab 85: 1143-1150.

15. Pedersen NG, Juul A, Christiansen M, Wojdemann KRTabor A, 2010 Maternal serum placental growth hormone, but not human placental lactogen or insulin growth factor-1, is positively associated with fetal growth in the first half of pregnancy. Ultrasound Obst Gyn 36: 534-541.

16. Liao S, Vickers MH, Taylor RS, et al, 2016 Human placental growth hormone is increased in maternal serum at 20 weeks of gestation in pregnancies with large-for-gestational-age babies. Growth Factors 34: 203-209.

17. Caufriez A, Frankenne F, Hennen G, Copinschi G. 1993 Regulation of maternal IGF-I by placental GH in normal and abnormal human pregnancies. Am J Physiol 265: E572-577.

18. Caufriez A, Frankenne F, Hennen G, Copinschi G, 1994 Regulation of maternal insulin-like growth factor I by placental growth hormone in pregnancy. Possible action of maternal IGF-I on fetal growth. Horm Res 42: 62-65.

19. Caufriez A, Frankenne F, Englert Y, et al, 1990 Placental growth hormone as a potential regulator of maternal IGF-I during human pregnancy. Am J Physiol 258: E1014-E1019.

20. Forbes K, Westwood M, 2008 The IGF axis and placental function. a mini review. Horm Res 69: 129-137.

21. Chard T, 1994 Insulin-like growth factors and their 
binding proteins in normal and abnormal human fetal growth. Growth Regul 4: 91-100.

22. Holt RI, Simpson HL, Sonksen PH, 2003 The role of the growth hormone-insulin-like growth factor axis in glucose homeostasis. Diabet Med 20: 3-15.

23. Fuglsang J, Lauszus F, Flyvbjerg A, Ovesen P, 2003 Human placental growth hormone, insulin-like growth factor I and -II, and insulin requirements during pregnancy in type 1 diabetes. J Clin Endocrinol Metab 88: 4355-4361.

24. Matuszek B, Lenart-Lipinska M, Burska A, et al, 2011 Increased serum insulin-like growth factor-1 levels in women with gestational diabetes. Adv Med Sci 56: 200-206.

25. Yan-Jun L, Tsushima T, Minei S, et al, 1996 Insulinlike growth factors (IGFs) and IGF-binding proteins (IGFBP-1, -2 and -3) in diabetic pregnancy: relationship to macrosomia. Endocrine Journal 43: 221-231.

26. Zhu Y, Mendola P, Albert PS, et al, 2016 Insulin-like growth factor axis and gestational diabetes: A longitudinal study in a multiracial cohort. Diabetes.

27. McCowan L, North RTaylor R. (2007).

28. Simmons D, Rowan J, Reid R, Campbell N, 2008 Screening, diagnosis and services for women with gestational diabetes mellitus (GDM) in New Zealand: a technical report from the National GDM Technical Working Party. N Z Med J 121: 74-86.

29. Solomon G, Reicher S, Gussakovsky EE, Jomain JB, Gertler A, 2006 Large-scale preparation and in vitro characterization of biologically active human placental (20 and $22 \mathrm{~K}$ ) and pituitary (20K) growth hormones: placental growth hormones have no lactogenic activity in humans. Growth Horm IGF Res 16: 297-307.

30. Liao S, Vickers MH, Taylor RS, et al, Human placental growth hormone is increased in maternal serum at 20 weeks of gestation in pregnancies with large-forgestational-age babies. Growth Factors 2016 Dec;34(56):203-209. doi: 10.1080/08977194.08972016.0127 3223.

31. Patel N, Alsat E, Igout A, et al, 1995 Glucose inhibits human placental GH secretion, in vitro. J Clin Endocrinol Metab 80: 1743-1746.

32. Bjorklund AO, Adamson UK, Carlstrom KA, et al, 1998 Placental hormones during induced hypoglycaemia in pregnant women with insulin-dependent diabetes mellitus: evidence of an active role for placenta in hormonal counter-regulation. Br J Obstet Gynaecol 105: 649-655.

33. Higgins MF, Russell NE, Crossey PA, et al, 2012 Maternal and fetal placental growth hormone and IGF axis in type 1 diabetic pregnancy. PLoS One 7: e29164.

34. Verhaeghe J, Pintiaux A, Van Herck E, et al, 2002 Placental GH, IGF-I, IGF-binding protein-1, and leptin during a glucose challenge test in pregnant women: relation with maternal body weight, glucose tolerance, and birth weight. J Clin Endocrinol Metab 87: 2875-2882.

35. Fuglsang J, Lauszus FF, Fisker S, Flyvbjerg A, Ovesen $\mathrm{P}, 2005$ Growth hormone binding protein and maternal body mass index in relation to placental growth hormone and insulin requirements during pregnancy in type 1 diabetic women. Growth Horm IGF Res 15: 223-230.

36. Clemmons DR, 2004 The relative roles of growth hormone and IGF-1 in controlling insulin sensitivity. J Clin Invest 113: 25-27.

37. Baxter RC, 1994 Insulin-like growth factor binding proteins in the human circulation: a review. Horm Res 42: 140-144.

38. Wheatcroft SB, Kearney MT, 2009 IGF-dependent and IGF-independent actions of IGF-binding protein-1 and -2: implications for metabolic homeostasis. Trends Endocrinol Metab 20: 153-162.

39. Collett-Solberg PF, Cohen P, 1996 The role of the insulin-like growth factor binding proteins and the IGFBP proteases in modulating IGF action. Endocrinol Metab Clin North Am 25: 591-614.

40. Kim HS, 2013 Role of insulin-like growth factor binding protein-3 in glucose and lipid metabolism. Ann Pediatr Endocrinol Metab 18: 9-12.

41. Kim HS, Ali O, Shim M, et al, 2007 Insulin-like growth factor binding protein-3 induces insulin resistance in adipocytes in vitro and in rats in vivo. Pediatr Res 61: 159-164.

42. Yamada PM, Mehta HH, Hwang D, et al, 2010 Evidence of a role for insulin-like growth factor binding protein (IGFBP)-3 in metabolic regulation. Endocrinology 151: 5741-5750.

43. Mohanraj L, Kim HS, Li W, et al, 2013 IGFBP-3 inhibits cytokine-induced insulin resistance and early manifestations of atherosclerosis. PLoS One 8: e55084.

44. Lee PD, Giudice LC, Conover CA, Powell DR, 1997 Insulin-like growth factor binding protein-1: recent findings and new directions. Proc Soc Exp Biol Med 216: 319-357.

45. Lewitt MS, Denyer GS, Cooney GJ, Baxter RC, 1991 Insulin-like growth factor-binding protein-1 modulates blood glucose levels. Endocrinology 129: 2254-2256.

46. Katz LE, DeLeon DD, Zhao H, Jawad AF, 2002 Free and total insulin-like growth factor (IGF)-I levels decline during fasting: relationships with insulin and IGF-binding protein-1. J Clin Endocrinol Metab 87: 2978-2983.

47. Rajkumar K, Krsek M, Dheen ST, Murphy LJ, 1996 Impaired glucose homeostasis in insulin-like growth factor binding protein-1 transgenic mice. J Clin Invest 98: $1818-1825$. 
48. Buyalos RP, Pekonen F, Halme JK, Judd HL, Rutanen EM, 1995 The relationship between circulating androgens, obesity, and hyperinsulinemia on serum insulin-like growth factor binding protein-1 in the polycystic ovarian syndrome. Am J Obstet Gynecol 172: 932-939.

49. Mogul HR, Marshall M, Frey M, et al, 1996 Insulin like growth factor-binding protein-1 as a marker for hyperinsulinemia in obese menopausal women. J Clin Endocrinol Metab 81: 4492-4495.

50. Luo ZC, Nuyt AM, Delvin E, et al, 2012 Maternal and fetal IGF-I and IGF-II levels, fetal growth, and gestational diabetes. J Clin Endocrinol Metab 97: 1720-1728.

51. Ramirez VI, Miller E, Meireles CL, et al, 2014 Adipo- nectin and IGFBP-1 in the development of gestational diabetes in obese mothers. BMJ Open Diabetes Res Care 2: e000010.

52. Hughes SC, Johnson MR, Heinrich GHolly JM, 1995 Could abnormalities in insulin-like growth factors and their binding proteins during pregnancy result in gestational diabetes? J Endocrinol 147: 517-524.

53. Qiu C, Vadachkoria S, Meryman L, Frederick IO, Williams MA, 2005 Maternal plasma concentrations of IGF-1, IGFBP-1, and C-peptide in early pregnancy and subsequent risk of gestational diabetes mellitus. Am J Obstet Gynecol 193: 1691-1697.

54. Verhaeghe J, 2008 Does the physiological acromegaly of pregnancy benefit the fetus? Gynecol Obstet Invest 66: $217-226$. 